\title{
BLOGS FOR WOMEN ENGINEERS: A MULTIMODAL STUDY
}

\section{BLOGS PARA INGENIERAS: UN ESTUDIO MULTIMODAL}

\author{
Silvia MOLINA-PlAZA
}

\begin{abstract}
Author / Autora:
Silvia Molina-Plaza

Universidad Politécnica de Madrid

Madrid, Spain

silvia.molina@upm.es

https://orcid.org/0000-0001-5537-7065

Submitted / Recibido: 09/10/2020

Accepted / Aceptado: 5/04/2021

To cite this article / Para citar este artículo: Molina-Plaza, S. (2021). Blogs for Women Engineers: a Multimodal Study. Feminismo/s, 38, 85-114. Women, Sexual Identity and Language [Monographic dossier]. I. Balteiro (Coord.). https://doi.org/10.14198/ fem.2021.38.04

Licence / Licencia:

This work is licensed under a Creative Commons Attribution 4.0 International.

\section{(c) (1)}

(C) Silvia Molina-Plaza

\begin{abstract}
This chapter examines thirty blogs for women engineers from a multimodal perspective, offering new ways of analysing their content and communicative strategies. The qualitative study focuses on how the interplay of different modes such as image, writing, typography and colour can be handled and how interpersonal and ideational realizations are construed. The final aim is to unravel relevant meaning-making practices used in these blogs, which want to achieve different objectives: overcome the limitations women still face in engineering by showcasing opportunities, change the perception of women engineers in society and redress the gender imbalance in engineering companies.
\end{abstract}

Keywords: Women Engineers; Blogs, Multimodality; STEM.

\section{Resumen}

Este capítulo estudia treinta blogs de ingenieras bajo un enfoque multimodal, con el objetivo primordial de analizar sus contenidos y estrategias comunicativas. El estudio cualitativo se centra en la sinergia de los distintos modos (imágenes, escritura, tipografía y colour) para transmitir contenido ideacional e interpersonal. Se pretenden desvelar las 
prácticas más relevantes para generar contenidos de calidad, que quieren alcanzar diferentes objetivos: superar las limitaciones a las que todavía se enfrentan las mujeres en la ingeniería mostrando las oportunidades, cambiar la percepción de las ingenieras en la sociedad y corregir el desequilibrio de género en las empresas de ingeniería.

Palabras clave: ingenieras; blogs; multimodalidad; carreras STEM.

\section{INTRODUCTION: SOME DATA ABOUT WOMEN IN ENGINEERING. MYTHS AND REALITIES}

Women and girls make up half of the world's population and therefore half of its potential. This means that engineering and gender equality are vital to achieving sustainable development in our society. The United Nations recognizes that the gender gap in the science, technology, engineering and mathematics (STEM) sectors has persisted for many years around the world, and although women's participation in higher education careers has increased tremendously, they are still underrepresented in these fields.

The digital transformation and the growing advances in science and technology give rise to new disruptive business models and with them, new professional profiles with very advanced technological knowledge and an ability to adapt to change as vertiginous as the evolution of technology itself. STEM careers are thus fundamental for this change worldwide, which have mainly helped countries to booster their economies. However, they are also the clearest example of gender inequality all over the world (Stout et al., 2011).

Why are there still more men than women in engineering in different countries? The disparity can be attributed to any of the three widespread myths, according to Osama, S. (2016):

- Myth \# 1 Men are better than women in Science: Science is one of the fundamental elements of engineering. To be a successful engineer, one has to have a good knowledge of many scientific concepts. And there is a widespread myth that men are naturally better in science than women. That is not the case. While it is true that men continue to dominate certain areas of science, there are hundreds of 
prominent examples -past and present- of leading scientific women and outstanding engineers.

- Myth \# 2 Women cannot get better grades: The opposite is in fact true; in recent years there has been concern in countries such as the USA and the United Kingdom on a gender gap in the opposite direction -with female students improving their academic performance and participation in higher education at a faster rate than men. In the United Kingdom, for example, statistics published in early 2016 showed that women outperform men in two-thirds of the degrees, and that among those from poorer settings; women were 50\% more likely to attend to college than their male peers.

- Myth \# 3 Women are good at soft skills, not techniques: This is one of the most difficult myths because it is still widely believed that women are better at «soft skills», while men are successful in the technical part. But talent is not linked to gender -although the prevailing cultural norms and stereotypes most likely influence the types of work that men and women decide to follow.

These are the myths. A few facts about reality: 17\% of the students enrolled in Spanish universities chose engineering and architecture studies last year according to data from the Spanish Ministry of Education published in The Spanish newspaper El Mundo (Lidón, 2019).Those who ended up in engineering schools represent a woman for every four future engineers, a proportion as uneven as that of three decades ago. The recruitment of female talent in the so-called STEM degrees is so worrying that the Spanish Royal Academy of Engineering has developed the Women and Engineering program to promote vocations -or at least prevent them from getting lost by prejudices and inherited stereotypes- while making women who are already leaders in this sector visible.

Sara Gómez, former Vice-rector at the Technical University of Madrid and current member of the RAI and director of Women in Engineering interviewed in the same article, tries to summarize three reasons why Spanish women are less attracted to STEM degrees; these are ignorance of the work engineers do: «nobody knows what we do even though there is not one single activity a day that has nothing to do with engineering and technology»; 
pernicious stereotypes that lead to the lack of adequate references and finally, a misconception of the difficulty involved in studying engineering. According to Gómez, in the last 20 years:

more than $20 \%$ of students in STEM schools in Spain have been lost, regardless of their gender. And the few women who have joined have done so in a very asymmetrical way. There are much masculinized sectors, such as software development and video games. Only $10 \%$ of the students go to computer science in Spain, a figure similar to that of the 80 s, while $50 \%$ go biomedicine or biotechnology, two new engineering fields. Women are attracted to both disciplines, to help others. [Comment on the article «iPor qué las mujeres no quieren ser ingenieras?» (Lidón, 2019)

Sara Gómez concludes by considering information and education as the only feasible alternatives to redress this unequal balance. A balanced gender representation in the media is also crucial to achieve equity (Popa \& Gavriliu, 2015).

Blogs are a useful tool for sharing this knowledge, experiences and skills about women in engineering. The body of academic research with a focus on the main characteristics of blogs has grown over the last years (Blood, 2000; Chandler, 1998; Daly, 1998). It is fairly evident that technical blogs may encourage more women in to STEM by giving access to all sorts of pragmatic information and education opportunities. The media attention and various blogs to support STEM education gives some hope that we will see an increase in diversity figures in the nearby future. Blogs for women engineers do a fine work in changing outdated perceptions and unconscious bias; they can also make a real difference, by showcasing the opportunities available to women in STEM and ensuring access to the same opportunities for all.

\section{OVERVIEW OF THE STUDY}

This paper looks at the different ways in which women's engineering blogs as samples of «situated activity» construct diverse women engineer identities mediated on the web. This puts the attention on discursive practices and the ideological discourse/s of promoting women in STEM. In particular, the study examines the main features of these blogs from a multimodal perspective (Machin, 2007; Pirini, 2017). Consequently, the focus is on how social identities, roles and relationships are enacted through the interplay of text 
and visuals, static and dynamic images (in videos); process types (whether women engineers are represented with active discourse roles or not) and the particularities of discursive strategies employed by female bloggers that can feed back into strategies for social change in engineering and technical fields.

The overarching goal is to provide an overview of the structure of these blogs to understand the communicative strategies women engineers use in evidencing their daily lives. To achieve this goal, the study first explores and explains the possible influence of engineering preferences and cultural values on the design and communicative style of blogs for women engineers in section 3. After that, method and data are described in section 4 and findings in section 5 .

\section{THE SUB-GENRE: BLOGS FOR ENGINEERS}

Before blogs existed, technical forms of writing have always relied on visual representation to represent new methods and concepts. Blogs build upon these older forms of expression and help engineers to develop their ideas in innovative, more complex ways. They develop as well as various discursive strategies that can be used in formal print texts, aimed at different kinds of audiences (mainly women engineers in general, women engineer entrepreneurs in particular), thus creating multimodal texts where different modes integrate print, visual and oral texts together, conveying how specialized engineers build products and work together. It is not merely a juxtaposition of different modes presenting the same information redundantly. The interplay of modes creates new meaning (Bateman, 2008: 2) and conveys ideas persuasively. An earlier, established genre (Technical Blogs) is re-designed and re-deployed by women engineers in a new, emerging sub-genre.

In engineering contexts, blogs are a useful technology for professionals for telling stories about their interests, concerns and work. Predictably, blogs promote certain preferences, skills and competences highly valued in engineering, such as project coordination, numerical skills, leadership attitude, initiative, social commitment, compliance with professional guidelines set by different engineering associations, etc. These core values highlight the importance of professional and personal growth in engineering. Fortunately, there are a whole lot more opportunities now in the twenty first century for 
those who were previously disadvantaged -including women. Engineering is still a highly technical field which can give rise to elitism in some circles or downright discrimination in others. Information is sometimes hidden away from women entering the field, making it even harder for them to achieve the competencies of their peers. This «glass ceiling» prevents women engineers from advancing to leadership positions and women's unequal status is reflected in blogs as a source of concern. How then do women in these (sadly rather common) circumstances achieve success despite crushing barriers? Table 1 summarizes some attitudinal strategies for success from engineer chic, a blog aimed at women engineers.

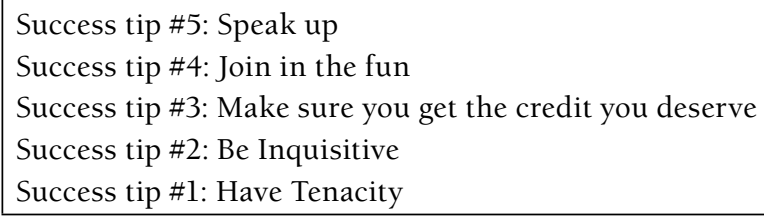

Table 1. Tips for a successful career in engineering for women.

Women engineers as members of specific discourse community also have to meet the criteria put forward by Swales (2004). They have a broadly agreed set of common public goals; they also have mechanisms of intercommunication among its members to provide information and feedback and, finally, they use a specific lexis which reveals their knowledge of relevant content and expertise.

In turn, it is necessary to observe the blog components in detail to explore their functional and cognitive characteristics. Table 2 sums up the basic structural components usually found in most templates for creating technical blogs, which have a similar format: header, main column, fixed side columns and footer. These four parts correspond to the public part of the blog, which viewers can see and through which they can navigate. This format is also commonly used in the engineering blogs in our corpus written by women. 
$\checkmark$ HEADER: It is the part where the blog title is located.

MAIN COLUMN: It is the place where the contents of the blog appear, that is, the entries, articles or "posts», with high-quality engineering content, linking them to other engineering works (intertextuality).

$\checkmark$ SIDE COLUMNS: Next to the main column of contents there is the possibility of inserting lateral columns to the right and / or to the left where other fixed elements of the blog can be added.

$\checkmark$ FOOT OF PAGE: It is placed at the end of the page and is another fixed element. It is the location for elements that do not require an outstanding presence or that do not alter the reading of the blog.

Table 2. Basic units in blogs.

Over the last few years, blogging has opened up a way for leading women in engineering to bring to light the important improvements women have made, the struggles they still encounter, and the strategies they set up for their work to be recognized. Specifically, these blogs offer career inspiration, when experienced engineers offer resources, ideas, and inspiration for helping other women to get ahead in their careers in engineering. This inspiration comes from the past: In what follows, the main features of these blogs for women engineers are described.

\subsection{Features of women's engineering blogs}

Nowadays, most female engineering bloggers customize a pre-given template rather than designing it from scratch. Choice of colours, visuals and typography is indeed meaningful to represent the main ideas of what they want to communicate (Kress 2010; Van Leeuwen 2011). When choosing a template, bloggers select a series of combinations which shape their blog's aesthetics as the most apt for their sign-making interests. Language with other semiotic modalities (layouts, visuals) fills in the template. A critical analysis of the visual rhetoric of these components makes for an enriching, holistic analysis of the discursive self-construction of women engineers.

The blogs in this sample are written by both women engineers and associations which promote engineering for women, trying to enhance them as professionals. A professional blog is a platform created to promote and develop other women's jobs. Through it, women engineers can promote their 
services, and even more importantly, networking. Engineering blogs for women also occupy a specific niche, as they are not intended to strengthen the brand image of a person, product or company, but to share issues that may be of interest and value for this certain niche, that of women engineers, such as the celebration of the International Women in Engineering Day -INWED, 23 June every year. (See Manríquez, 2020).

The potential audience is mixed: mainly women engineers, women engineering entrepreneurs and readers who can eventually become customers (in the case of personal blogs). There are different authors with content of interest, news, tips and curiosities around the world of engineering and women working in this field. To a lesser extent, the corpus sample also includes personal blogs by women engineers, who mainly seek a platform for free speech and promotion. They update other women engineers on engineering activities and whereabouts, express their own opinions to influence others and also seek others' opinions.

From a formal perspective, table 3 illustrates the main formal features found in women's engineering blogs both in the UK and Spain. This discourse community of bloggers cannot be dissociated from their social context and their blogs present a specific type of social interaction. Blogs are used to stay in constant contact with other engineers and stakeholders. That is the main reason why engineering blogs display an ability to gather information, argue proposals, solutions and results in an attractive manner. For any engineer numbers and calculations must be accurate, so that the works or projects are efficient. The same goes for blog writing. The communication must be $100 \%$ clear; otherwise, the consequences are greater, because time and money are wasted.

- Entries: or «posts». These entries appear in reversed chronological order, (most recent first) each time a new one is published.

- Static and dynamic pages: if we adjust to the definition of what a blog is, it is a website whose content is dynamic since entries are added every so often. However, a blog also has static pages; generally there are two, «Contact» and «Who we are».

- Use of different modes for content: traditionally, blog posts have been composed of text and the occasional image accompanying it. However, for several years, many users try to attract visitors using other modes to present complex information: animations, infographics, photographs, etc. 
- Organization: the vast majority are organized using tags and categories. The objective is none other than to facilitate as much as possible the search of content within the blog to visitors.

- Web Traffic: it allows building relationships of trust among users, thus humanizing the women engineers in question.

- Bidirectional communication: the audience, women engineers, has the option to interact with the people behind the blog in question through comments. Collaborative engineering activity, supporting future work of other women engineers.

- Keywords: in blog posts, keywords and key-word rich titles are essential (Women's Under-Representation, women's career development, women engineers, connect, collaborate)

- Language: entries are concise and well-written: women engineers use short and simple sentences and paragraphs; eliminate redundant words and expressions, they «stick to the point».

- Authorship: the aspects of instant feedback and increased collaboration dilute the notion of individual authorship to a certain extent. However, some blogs include clearly the author of each post (mujeringeniera.com/ingenieriapetrolera)

- Videos: some engineering blogs include videos. More often than not, viewers will end up engaging with the content by clicking on the video because it stands out in the midst of all text in the women engineering blog post (https://www.mujeringeniera.com/talentos-ocultos-pelicula-mujeres-ingenieras)

Table 3. Formal features of women's engineering blogs.

From a socio-cognitive approach, women's engineering blogs reflect diverse ways of thinking about women engineers that construct them as such. These blogs structure what women engineers hold as true and what they act upon. They foster collective dissemination of engineering knowledge and peer discussion.

\section{DATA AND METHODOLOGY}

This study is based on the multimodal analysis of thirty blogs randomly selected and recorded for the purposes of analysis in March 2020 from the web. The goal of the study is to focus mainly on the qualitative analysis of these blogs to examine their power to frame concepts for women engineers. It consists of two steps: first, an overview of the 30 blogs in order to find out (a) whether their multimodal features act as a genre, and (b) whether there are differences between personal and institutional blogs in the sample. Once 
these general aspects have been identified, four representative blogs (two personal and two institutional) have been selected for detailed discussion.

Multimodality has attracted many scholars interested in communication and semiosis, and there is now a substantial body of scholarly work focusing on the multimodal dimensions of discourse as a social practice. One relevant concern of multimodality is studying how language is nested in other modes (Jewitt, Bezemer \& O'Halloran, 2016: 17-18). Multimodality stresses that «modes work together to produce a greater meaning than either mode could on its own» (Rowsell, 2013: 147). Specifically, this study applies the analytic tools proposed by Kress \& van Leeuwen (2006) to examine the interpersonal discursive construction of meaning in the websites for women entrepreneurs: gaze, mood and social distance. Gaze is a socially organized way of viewing and experiencing the world, hence visual contact on a blog homepage determines the type of relation between the viewer and the blog designer. Secondly, mood refers to how bold and saturated colours may communicate emotional intensity (interpersonal function). Thirdly, social distance refers to how women engineers are presented to the audience by checking the different sizes of their photos (framing). In addition, attention is focused on the particular process types (whether women engineers are presented with active or passive discourse roles) and the self-constructed dynamic identities of women pertaining to engineering networks as institutional actors with their discursive practices, i.e., how the adopted presentational styles reflect women engineers sociocultural values. Finally, Van Leeuwen's (1996) framework for the representation of social actors and social action in discourse are also adopted.

Research on the multimodal rhetoric of discourse has grown in the last decade or so (Bezemer $\&$ Kress, 2008; Buehl, 2016). Generating or inventing ideas and lines of arguments in a blog is in itself an exercise that fulfils both the ideational and the interpersonal functions of discourse. Hence, this study aims to determine the persuasive strategies used by the multimodal discourse producers, and to see how this social group creates a coherent discourse establishing ethos and appealing to logos and pathos for other women engineers and readers. The analysis focuses on the blog homepages as primary entry points to the blogs, current platforms for engineering communication. 
As regards the data, this study is based on the analysis of 30 blogs from the U.K, USA, Canada and Spain; twenty institutional and ten personal blogs of women engineers. Institutional blogs from Spanish Universities (Universidad de Alicante; Universidad Politécnica de Madrid; Universidad de Castilla-la Mancha) and engineering associations (for example, the blog from the Women's Engineering Society in the UK) represent high-status women engineers and examples of successful young women to attract the young girls to join the ranks. They also highlight engineering team's culture, and introduce the talented engineers on an institution. Personal blogs keep engineers on the pulse of what's happening in their technical field -research, innovations, products, events and business inspiration. The role that these women as social actors are given to play in both types of blogs is «agent» (actor). The sample of blogs was selected in 2019 typing in Google «blogs for women engineers» in English and Spanish. Representative institutional and personal blogs of different areas in engineering were selected from English and Spanish sources.

One of the problems faced during the sample collection was the dynamicity of blogs. The front pages of a blog are short-lived as a consequence of its need of updating. To overcome this limitation, screenshots of the blogs front page were taken. Once each blog was compiled, it was numbered and codified by date and time and given a code. Then the text and the accompanying images were linguistically annotated and analysed manually.

\section{FINDINGS AND DISCUSSION}

This section provides an overview of how women engineers' concerns interact with different modes and rhetoric in our sample of blogs. The layout of women's engineering blogs is strongly connected to the process of building a public image of women as professional engineers. The initial inspection of the homepages aimed to determine how different multimodal resources were arranged into clusters and different units of meaning. Noteworthy, these blogs select the trendiest and most impactful production of photography and typography. Even more significant, however, is the fact that almost all blogs display images of women and combine large size image with short text in the central position. The fact that around $95 \%$ of the homepages display 
photography of real women is very revealing. Gender identity, contextually constructed through entries and in constant flux, is highly present in these women's engineering blogs. The images used denote women who have to position themselves within the world of engineering nowadays.

First, general findings are addressed, in particular with reference to the way these blogs are usually structured in 5.1. Next, I analyse in depth four representative blogs which illustrate different patterns found in these blogs in 5.2 .

\subsection{MULTIMODAL TOOLS IN PERSONAL AND INSTITUTIONAL WOMEN'S ENGINEERING BLOGS}

Analytically, it useful to consider the following categories/modes as separated (Bezemer \& Jewitt, 2010) to identify their precise functions in blogs:

a. Page layout: refers to the arrangement of text, images, and other objects on a page through framing and positioning; framing includes all devices that connect and/or separate elements; positioning refers to the relative position of the elements on a page (Kress, 2010). Blog designers tended to favour a minimalist design in our sample with lots of uniform, open space.

b. Colour: it is used in framing devices, in images and fonts; modal elements of colour include palette and effects, such as lighting, saturation and nuancing (Kress \& van Leeuwen, 2006). Colours subconsciously elicit thoughts and emotions when users see them. The favourite ones in this sample were purple, blue and green with different shades (Navy Blue, Jade, Grape). Purple has a strong emotional resonance for many women as it symbolizes sisterhood, the women's movement, achievement gained and achievements yet to come; different shades of blue were also preferred colours that transmit a subtle message of trustworthiness and serenity. It is used for example in the blog sponsored by the University of the Basque Country Mujeres con ciencia [Women with Science] (Pérez, 2020). Generally speaking, these blogs normally used three colours, excluding black and white. These three colours may be considered as splashes of colour that 
call attention to different parts of the blog to add visual appeal (i.e. the Society of Women Engineer's blog uses purple and two shades of blue, appealing colours to female engineers). However, this was not always the case. Other blogs used five or six colours, and some used just one or two. In order to create a harmonious design, these blogs tend to follow the 60-30-10 rule, which means that 60 per cent of the design is covered by a primary colour and 20 per cent by a secondary colour, as in Women in engineering blog.

c. Font: refers to the material shape of writing and is meaningful through font type (bold, italics and capitalization) and size (Bezemer $\&$ Kress, 2008). Interestingly, these blogs favoured simple fonts such as Arial. Font size also plays an important role whether an engineer will read a post or just ignore it. For example, «Women Engineers Needed - Join a Network for Support» written in a giant print (24 point) and bold type definitely draws the viewer's attention and creates salience (Munn, 2014).

d. Writing: blog posts in this study tend to avoid long chunks of text. One of the possible reasons behind this being bloggers just have about 50 milliseconds to make a good first impression. Posts in the sample are short, informative and focus on the quality of the content. The sentences tend to be single clauses or involve simple coordination ('and'). They are written to convey facts with clarity. Writers also write detailed, precise and logically sequenced posts. This specific vocabulary and grammar combine with factual precision to produce the expected register of engineering writing. Other features to be taken into account are instances of anaphoric cross-reference between messages; general feedback reactions found as opening sentences; use of certain types of grammatical constructions (i.e. active sentences), jargon or abbreviations, thus sharing linguistic character with interlocutors; and, finally, use of rhetorical questions or tag questions state personal opinions and/or stress an utterance.

An overview of the blogs revealed patterns of syntactic compression in personal blogs, such as omitted determiners, conventionalized use of past participles and present tense verb forms. The ease 
and low cost of publishing via blogs also involves using keywords related to each specific technological area: computing, electronical engineering, etc. In addition to the information presented in text, bloggers use the properties and resources of hypertext. These links and references add relevant additional information without extending the content and agility to the post. Thus, women engineers as authors filter out engineering web content and only let access to an edited version of the Web. Multimedia elements such as images, videos, audios, etc. associated to the article also provide additional powerful information and files hosted on other websites can be referenced.

e. Visuals: Image can be still or dynamic; it can be a photograph, a drawing, a symbol/shape, a diagram (often combining image and writing) or a video (which combines auditory resources too); image makes meaning through framing, modality, camera angle and others (cf. Kress \& van Leeuwen, 2006). Blogs in our sample tend to use frontal close-up photos of women engineers at eye level, which highlight an equal relationship with the viewer (Kress \& van Leeuwen, 2006: 12). To a lesser extent, medium-long shots showing women engineers in their everyday activities, capturing their performance and surroundings.

f. Interactivity and combination of modes: Blogs are aimed at being interactive and women engineers comment on blog posts; these comments can be quickly and easily accessed by other women engineers once they are posted. The homepage in these blogs, as a kind of webpage, is visually dynamic and requires different levels of interactivity from users (Adami, 2015). Bateman et al. (2017, p. 305) identify three levels of interactivity: the lowest as the initial exploration, the middle where the viewer proceeds with the manipulation of slides or menu and the highest level when the viewer performs a choice over one of the elements. The present study focuses on the lowest level of interactivity and examines the clusters made salient independently from any affordance made available to use it at higher levels of interactivity. Finally, the combination of modes explains how that range of 
meanings fulfils the blog's function and expresses the desired social relation with the audience.

Next, the difference between personal and institutional blogs is discussed, one of the goals of this study. The fine-grained analysis of these blogs pays attention to socio-cultural and individual aspects of semiosis, including various modes, such as layout, font, colour and photos. Individual women engineers writing on their personal websites address an audience interested in technological topics and career development, or any women engineers who 'follow' the blogger. The purpose is to express their personal opinion mainly on technical issues but also on women's situation in engineering. Stance features are integrated with other ideational lexico-grammatical features to express personal attitudes and evaluation. Overall, personal blogs tend to be quite informational and give advice to other women engineers using modal verbs, aspect verbs and process nouns. They describe the future actions that women engineers should undertake to be successful in engineering, using visual credentials (e.g. actors are seen in the lab or surrounded by computers). From a linguistic point of view, personal pronouns and deictic features are related to assumptions about audience (other women engineers and employers) and context. The pronoun 'you' can be generic (the writer does not know the individual identities of other women that the message is aimed at), but is has some pragmatic force as this pronoun is used in one-to-one spoken interaction. Besides, these individual blogs commonly include deictic markers such as 'this, here, there', which may refer to the space the engineer inhabits or the virtual space of the blog page itself.

In institutional blogs respected women engineers also write for readers interested in engineering topics. There is a complex mix of communicative functions here. Discourse is usually framed as information but it also has a covert function: to encourage especially young women to enrol in engineering. For this reason, institutional blogs include narratives or evidence of successful women in technology. They usually have a present-time orientation and reveal a frequent use of stance features. In particular, their grammatical and multimodal style approximates the average of other website-based forms of communication (institutional webpages for companies 
or political institutions) and certain analogies with print publishing can be found. Furthermore, institutional blogs include simple noun phrases (i.e. members, jobs, partnerships, etc.) usually found inside a bar -a graphological way of signaling broad semantic categories the visitor of the engineering blog may be interested in or focusing on the group that a reader of the site may identify why (e.g. students, regional clusters). They normally include a brief introduction: Quiero ser ingeniera [I want to be a woman engineer], followed by role models, specific examples of women engineers in a newsbite format, i.e. short enough extracts of their biodata to be read in their entirety on the screen, as in the blog published by the Library at the University of Alicante (Quiero ser ingeniera, 2019). A relevant example from the past (Fairer Science) is the following:

It's Ada Lovelace Day. As many of you know, today is Ada Lovelace Day where science bloggers are encouraged to "write a blog post about your STEM heroine». I had a lot of thoughts about who to write about, but then I read an NPR story, The Forgotten Female Programmers Who Created Modern Tech and realized that there are many people who don't know who Ada Lovelace is. (Pat, 2014).

\subsection{Types of women engineers and modes of representation in four blogs}

Based on the blogs analysed for this study, the following types of social actors are typically represented in women's engineering blogs.

\subsubsection{Institutional Affiliates}

Access to the specialized discourse domain of engineering is normally restricted to professional engineers, which I call «institutional affiliates». These are women who represent different engineering organizations in different capacities (President, Vice-president, Trustee, and Ordinary Council Member). The discourse role of these participants is obviously varied, according to the cultural norms of each association and their institutional practices. This study is interested on the identities and positions these women create for themselves in their blog interaction. 
These institutional blogs tend to follow a hierarchical structure. At the top of the pyramid is the president or vice-presidents who mediate and frame the most important topics. They have the authority to speak on behalf of other women engineer as experts. They are an easy way of getting information online, either to show other women engineers or for them to find on their own. It's just a way to connect professionals with that they need.

A Spanish example of institutional affiliate is the Sara Gómez, a leading member of the Spanish Engineering Academy (Table 4). Her biodata has 157 words, giving essential clues about her professional identity. This is a fairly standard format. The interplay of the written text and the visual is fairly conservative, following the conventions for the production of academic curriculum vitae. As a matter of fact, it looks like the traditional printed version of a $\mathrm{CV}$ revealing the construction of a coherent trajectory as engineer and, thus, projecting a coherent sense of self. Her expertise is stated explicitly by mentioning her credentials. Typically, her legitimation as expert takes the form of verbal process clauses with Sara as subject («she works at the Technical University of Madrid, whose acronym in Spanish is UPM).

On average, a woman's engineering biodata ranges from 150 to 250 words. The central role of identity in workplace interactions and public fora -how people perceive themselves and their colleagues at work- has been the subject of several studies (e.g. Angouri \& Marra, 2011; Schnurr, 2013; Schnurr \& Zayts, 2017). In the role models section in blogs, the most straightforward and frequent way of organizing information is to put old information in theme position and new information towards the end of the rheme, as in Sara Gomez's curriculum. 
Sara Gómez Martín

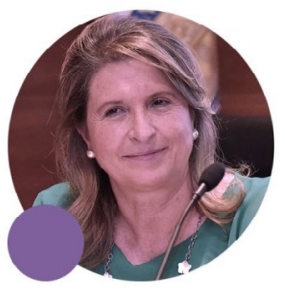

Es Ingeniera Técnica en Mecánica, Ingeniera de Materiales y Doctora Ingeniera por la Universidad Politécnica de Madrid (UPM), donde trabaja desde 1985 como profesora e investigadora en la Escuela Universitaria de Ingeniería Técnica Industrial, en las áreas de mecánica de los medios continuos y teoría de estructuras.

Ha trabajado en distintas compañías privadas e instituciones públicas como la Oficina de Transferencia Tecnológica de la UPM (OTT). Fue gerente de la Real Academia de Ingeniería, de 2000 a 2004; directora de la Escuela Técnica Superior de Ingeniería y Diseño Industrial (Universidad Politécnica de Madrid) (ETSIDI), de la UPM, de 2008 a 2012, y vicerrectora de la UPM, de 2012 a 2016.

Desde julio de 2016 es consejera de la Real Academia de Ingeniería y directora del proyecto Mujer e Ingeniería.

Actualmente dirige el Grupo de Investigación Diseño y Tecnología Industrial y está muy involucrada en terminar con «el techo de cristal de las mujeres en el mundo tecnológico».

Table 4. Sara Gómez's biodata in «Quiero ser ingeniera» [I want to be a female engineer]

On average, a woman's engineering biodata ranges from 150 to 250 words. The central role of identity in workplace interactions and public fora -how people perceive themselves and their colleagues at work- has been the subject of several studies (e.g. Angouri \& Marra, 2011; Schnurr, 2013; Schnurr $\&$ Zayts, 2017). In the role models section in blogs, the most straightforward and frequent way of organizing information is to put old information in theme position and new information towards the end of the rheme, as in Sara Gomez's curriculum.

Now, I am going to describe the way in which the interaction between different modes takes place and how social actors are presented in another institutional blog, Stemettes (Figure 1). It is an organization based in the 
U.K. that strives to inspire and motivate the next generation of females in STEM fields; they aim to do this by giving them access to events, hackathons, mentoring schemes etc. For this purpose, micro and macro level multimodal strategies are used. Examples of micro level strategies are big capital letters in bold type for the expression of a verbal message: STEM MODE IN, which enhance the photo and the efforts against the Covid-19 pandemic. The photograph of young women engineers in combination with typography is also meaningful and salient. Their smiling faces add a human touch to the blog and trigger positive emotions, enhanced by their mutual gaze and postural orientation toward one another. Close-up shots of women engineers at eye level stress «an equal relationship with the viewer» (Kress \& Van Leeuwen, 2006: 12). Calls to action are hyperlinks in blue in the text below the headline: «response to the Covid-19 outbreak», «bookmark the page» or «sign for updates here».

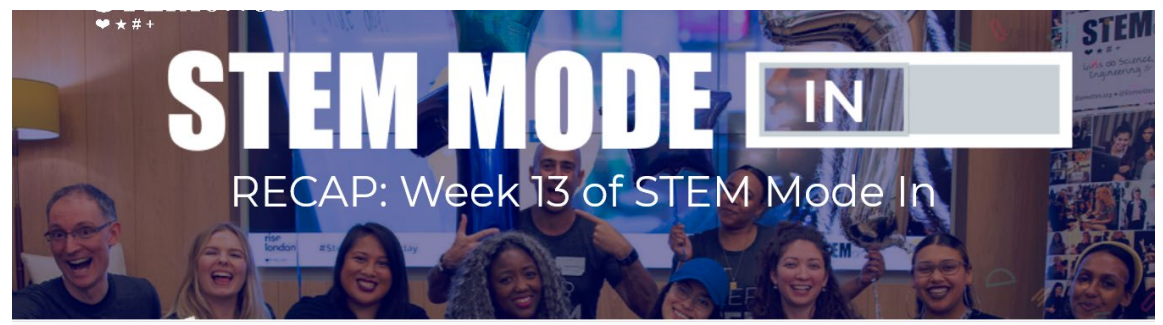

Posted by, adminz

As part of our response to the Covid-19 outbreak, Stemettes is running 12 weeks of online events for our community and the wider public. The full timetable is up on our website and is being updated as we pull the schedule together. Bookmark the page and keep checking back so you don't miss out. We're also sending an email out every Friday to let you know what's happening the following week - sign up for updates here.

\section{Tags}

Accenture Ada Lovelexe Day Anita Borg Institute

Bank of America Merrill Lynch blog Born to Be coding covid-19 Deutsche Bank Engineering Entrepreneurship

Figure 1. Stemmetes' blog.

\subsubsection{Individual Social Actors}

As a user's point of entry to a blog and its meanings (Baldry $\&$ Thibault, 2006), the homepage plays an essential role in conveying the contents and functions of personal blogs. In contrast to institutional blogs, they express 
the «author's voice» and have a more creative, reflective stance but they also reflect functional writing, such as problem-solving skills. Personal blogs help engineers to obtain the best solution possible with the resources available.

The analysis of the multimodal meaning enacted focused on two areas. The first area was concerned with the design features contributing to the creation of the blog message(s) through visual and linguistic elements. The second looked into the hierarchy of themes signalled by these features and its potential in revealing not only how content is structured and made coherent in the blog but more importantly, what elements are chosen as ideational points of departure for its message.

Their main linguistic features of these stories are use of contracted forms, beginning a sentence with a coordinating conjunction replacing a word by a number ( $« 5$ days, 2 weeks, 2 hours»), and omission of punctuation signs, such as missing commas or suspensive dots. Reflective writing about the role of women in engineering blogs also involves a more personal style and the woman engineer puts her thoughts and feelings at the centre of the task. Therefore, personal pronouns such as - 'I', 'me', 'my' - or even 'we' are both acceptable and typically found.

As regards page layout, personal blogs tend to use a header with the menu or navigation bar to declutter the page and make a great first impression. It is followed up by main content area on which blog posts appear either by order of publishing or by relevance. The homepage also uses headlines as attention grabbers. A nice example is mujeres ingeniosas (witty women), a pun playing with the adjective «ingeniosa» (witty) and the noun ingeniera (woman engineer). A compelling headline like this one instantly generates clicks, drives traffic, and entices other women to read on. The comment section is typically located at the end of every post, as a place for women engineers to engage in an exchange of ideas. Down below are contact pages, privacy policies, and relevant links, neatly arranged in a footer. Optimizing content for search on engineering websites and sharing within different social channels is essential for reach and engagement of engineering blog content. Another important feature is that blogging platforms are nowadays mobile-ready: Women engineers use Wordpress, Blogger, Tumblr, which 
create attractive, functional mobile versions of their blogs (and associated sites).

Finally, a sidebar usually located on the right highlights favourite entries, with social profiles, favourite content and call-to-actions

The real revolution in engineering has been brought about from the fact that any woman engineer can put up her own site without, initially, having it vetted by anyone to create her own personal blog.

This study is interested to find out if personal home pages by women engineers have a language of their own and the way it interacts with other modes. Personal blogs by women engineers seem to be a curious hybrid of secret diary and public, factual information and revelation about what is like to be an engineer for women (i.e. Laura Medalia's blog). Laura Medalia is an engineer who loves computer science and fashion and invites others to «embrace a girly side of tech». She focuses on the production on newsbites she considers newsworthy or practical for other girls in tech and addresses issues such as self-exploration as well. Figure 2 shows her post «Productivity Tips» (Medalia, 2017) is a close-up showcasing Laura's immediate visual context and reveals what she does to stray productive: a coffee disposable cup with and action key verb in computing («code», repeated in caps attracting the viewer's gaze) and computers. Her posts identify with recent events and are coherent with ideas and understandings that are popular in computing. Readers see some relevance to their own lives as women involved in technology. Her blog is attractive for young engineers because she draws on the values of personalization and the best of computer technology. 


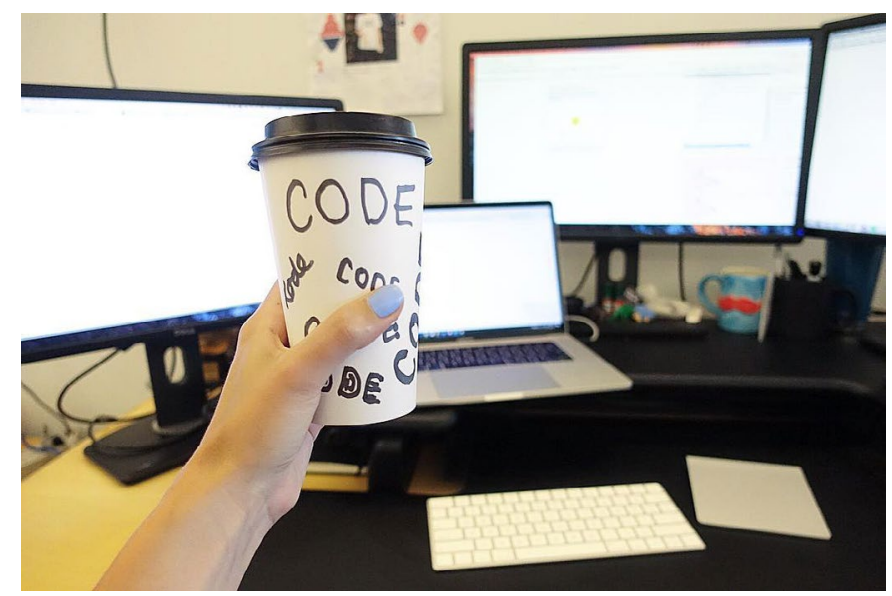

Figure 2. Snapshot from Laura Medalia's blog

Other personal blogs in the sample also contain statements, reflections and sentiments for the rest of the world to see and sometimes are a medium for the presentation of the self. A case in point is Girls in Tech, composed of different testimonies of women working in engineering topics (figure 3).

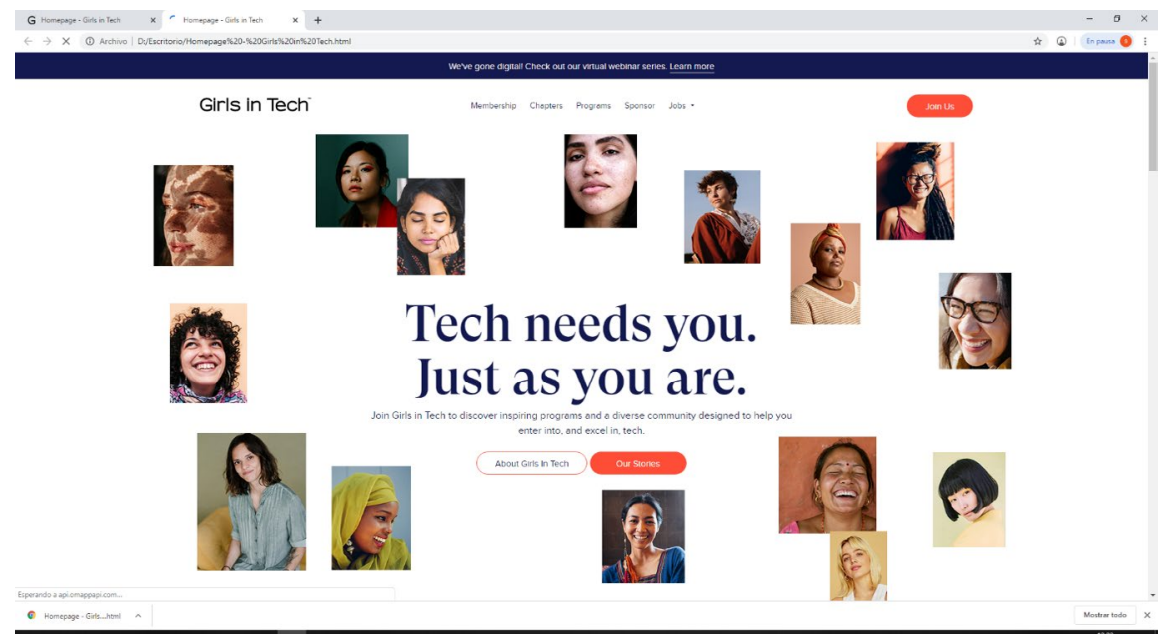

Figure 3. Testimonies of Women engineers (Girls in Tech)

Feminismo/s 38, July 2021, 85-114 
The homepage layout of Girls in Tech is a complex multimodal sign, consisting of a range of photographs of smiling women engineers of different age groups and ethnic backgrounds, framed as members of the same community of women engineers. Paramount in the data segment is how gaze and postural orientation of the women engineers as social actors is mutually influential as they seek a position of shared knowledge and understanding which will allow them to move forward in their professional careers. Simultaneously, the range of photos with the written message «Tech needs you just as you are» functions as a coherent visual-verbal sign, which honours women for their courage despite the hegemonic masculinity in engineering. This page draws the viewers' attention to the merits of women engineers and tries to link women engineers as members of a wider social network, using hyperlinks and different modes.

Additionally, there are navigation tools around the blog, such as headings of various sections («jobs», «programs»), search functions and newsbites of women in engineering that enable viewers to click through to the full testimony of diverse women engineer role models, called here «our stories», salient for its central position in the centre and its bright orange colour. The multimodal nature of the blog allows for new, more appealing modes of communication and interaction between women engineers as «producers» and other women engineers as «viewers». The possibility to comment on stories online related to other women in engineering often leads to feedback and conversations between contributors. It is evident that blogs such as this one frame women engineers as social actors and are a powerful means of paying attention to the way information about women in technology is filtered and represented, how ideology about them can be recovered by analyzing lexical, syntactic and visual choices and how «stories» are structured in order to represent a more inclusive point of view in engineering.

As a summary of results, a multimodal approach offers potentials for investigating communication in the following respects:

From a general perspective, these blogs are calls-to-action designed to get an immediate response from women engineers, aimed at influencing any of the following aspects: 
- To make known the diversity of professional opportunities in engineering: showing that they are also professions with a social purpose, an aspect that seems to have a significant influence on young women when they select their studies. They tend to use newsbites, relying increasingly on visual communication in order to position content and attract readers.

- To make visible the work and achievements made by women engineers and technologists throughout history. The lack of female referents may be a reason why there are fewer girls interested in these studies. That is why institutional and also some personal blogs include a role models section (past and present).

- To make a connection with other women engineers. Speaking in first person (I, We, ourselves) is an effective way women engineers use to personalize their writing and to appeal to emotion.

These topics are visible in social keywords (gender equality, visibility, women in science), which represent topics of interest to the women's engineering blogs is intended to reach and engage. By researching these topics and the specific language the community uses to express their interest, blogging becomes more effective at being relevant and shared on different social webs.

From a multimodal and qualitative perspective, the use of written and visual elements is considered. As far as the images are concerned, they portray individual women engineers or small groups of women at interpersonal interaction. They are presented in combination with the verbal message. A good example is figure 4, which illustrates the homepage for 'I want to be a female engineer' [Quiero Ser Ingeniera, Universidad Politécnica de Madrid] (Haciendo balance, 2019). As the viewer may observe, the idea «I want to be a woman engineer» is partially shown (a graphic on the top right corner with a girl plus the written message partially clipped). The photo of a competition with students implicitly suggests what message is being highlighted. Although the message cannot be seen, the phrase highlighted in bold type haciendo balance [taking stock] works in combination with the group photo to suggest that this blog is about promoting women in science by means of a project, as stated explicitly in the written text (Pilot Project QSI, whose Spanish acronym corresponds to «I want to be a female engineer»). The 
organization of verbal and visual elements on the page runs on a diagonal axis, from the left top corner towards the right bottom. Social network icons are placed there.

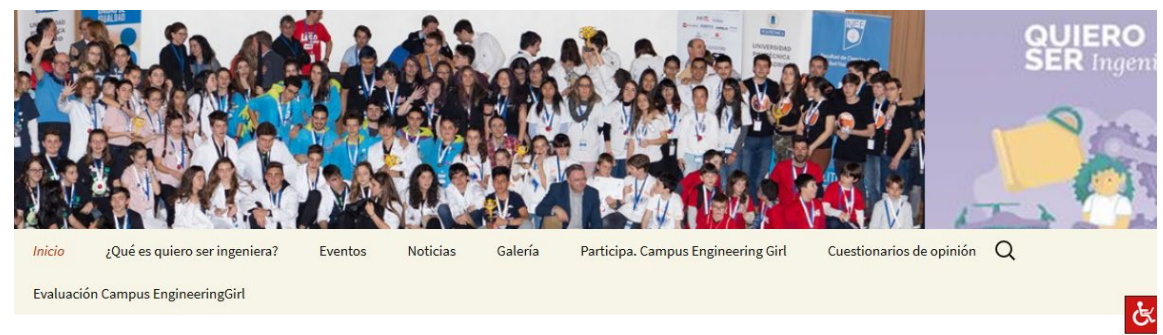

\section{Haciendo balance}

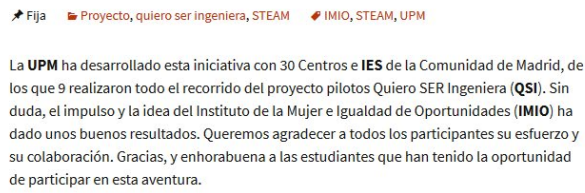

Figure 4. I want to be a female engineer. Institutional Blog sponsored by the Technical University of Madrid.

\section{CONCLUDING REMARKS}

The purpose of this study was to illustrate the potential of multimodality with the subgenre of blogs for women engineers to produce creative and persuasive messages. These blogs, public fora of interest in present-day women studies and discourse research, are not just about conveying engineering content but also about the representation of themselves as women in engineering. Blog writing is an act of identity in which women engineers align themselves with current socio-culturally shaped subject positions, and thereby play their part in reproducing or challenging dominant engineering practices and discourses, and the values, beliefs and interests which they embody.

These blogs are clearly socially-situated practices, where women identities are performed socially through their semiotic practices, as well as being defined by engineers' membership status. Personal and institutional blogs 
help to position the self in relation to others and they are at the same time incredibly powerful tools for publication and communication for women in engineering that favours the exchange and debate of ideas, finding new information and, even more importantly, networking. Meaning-making is fluid and transformative in these personal blogs, rather than relying on existing codes. A few bloggers challenge male dominant discourses in engineering.

The women's engineering blogging community or «blogospheres» is increasing in the social, cultural, political and educational aspects, since the authors have total independence to write about what they deem appropriate in their own blog; blogs are a good indicator of what really worries women in engineering fields.

This chapter has tried to demonstrate that a multimodal framework used for an in-depth analysis of the interplay of verbiage and image can be applied effectively to these blogs as contextually motivated asynchronous communication. Women's Engineering blogs present a version of women professionals constructed for the consumption of an unknown public of experts. The narrative voice, particularly in personal blogs, very often presents itself as if it is involved in one-to-one interaction, with an imaginary reader. Female bloggers express themselves creatively in order to document their personal experiences or share them with other women engineers to strengthen bonds within the community, plus sharing pragmatic contents with others.

Bloggers need to secure a dominant subject position as professional engineers in a still male-dominated engineering industry. They do so by applying multimodal strategies of self-fashioning and by differentiating themselves from other professionals, male engineers.

In conclusion, these blogs allow women engineers to actively produce their own diverse identities that foster each blogger's self-representation uniting the genre-specific narrative constructs of the weblogs and the specifics of engineering technological writing.

No doubt, the study of blogs is a complex issue as several factors must be taken into account in the construction of women engineers. The qualitative study of blogs has enabled a fine-grained analysis of some of the multimodal tools used in this sub-genre (colour, typography, visuals, etc.).

Overall, these blogs reveal that to be a woman engineer in the 21 st century is still a challenge. On a brighter note, women engineers have achieved 
many things over the past century. However, there is always room to grow and progress as seen in blogs, and many women hope to continue the true essence of feminism -achieving gender equality step by a step in diverse engineering fields.

\section{APPENDIX WOMEN'S ENGINEERING BLOGS}

1. Asociación ingeniera.soy. https://www.ingeniera.soy/\#blog

2. Blog Biblioteca Universitaria Universidad de Alicante. https://blogs.ua.es/ bibliotecauniversitaria/2019/03/01/quiero-ser-ingeniera/

3. Blog Ferrovial. https://blog.ferrovial.com/es/2019/06/dia-mujer-ingeniera-loque-las mujeres-con-ingenio-consiguieron-para-la-generacion-de-hoy/

4. Blog from Bibliotecas del Área Tecnológica de la ULPGC. Mujeres ingenierasINTELING (ulpgc.es)

5. Blog from Girls in Tech. https://girlsintech.org/

6. Blog from Workflow. https://www.workflowmax.com/blog/27-resources-to-educate-celebrate-and empower-female-engineers

7. Blog Mujer Tech. https://mujertech.womenalia.com/

8. Blog Universidad Castilla-La Mancha. http://blog.uclm.es/mujeringenieria/

9. Blog Universidad Politécnica de Madrid. https://blogs.upm.es/quieroseringeniera/

10. Caixa Enginyers' Blog. https://blog.caixa-enginyers.com/mujeres-ingenieraslas-protagonistas-de-la-fundacion/?lang=es

11. Electrifying Women. https://electrifyingwomen.org/blog-2/

12. Engineer chic. Womxn in technology and engineering. https://engineerchic. $\mathrm{com} /$

13. Engineering Emily. https://www.engineeringemily.com/

14. Fairer Science blog. http://www.fairerscience.org/fs-blogs/index.html

15. Flexbot. https://www.flexbot.es/mujeres-ingenieras-en-la-actualidad/

16. Girl Knows Tech. https://girlknowstech.com/category/blogging/

17. IEE Women in Engineering's Blog. https://www.facebook.com/page/ $150443418299658 /$ search/?q=blog

18. Inspiring Women Blog. https://itfinspiringwomen.wordpress.com/2017/05/05/ more-female-role-models-needed-as-over-half-of-older-teens-ready-to-ruleout-a-career-in-science/

19. Laura Medalia's blog. https://www.lauramedalia.com/blog/

20. Mary Rose Cook's Blog. https://maryrosecook.com/blog/

21. Miss Aerospace. http://www.missaerospace.com/ 
22. Mujer Ingeniera. https://www.mujeringeniera.com/

23. Mujeres con ciencia: Un blog de la Cátedra de Cultura Científica de la UPV/ EHU. https://mujeresconciencia.com

24. National Centre for Universities and Business. https://www.ncub.co.uk/blog/ engineering-diversity.html

25. SpringerOpen Blog. http://blogs.springeropen.com/springeropen/2018/05/23/ being-a-women-in-engineering/

26. Stemettes' Blog. https://stemettes.org/blog/

27. The female engineering Blog. https://thefemaleengineerblog.com/

28. UK Space Agency Blog. https://space.blog.gov.uk/2017/06/22/celebratingfemale-space-engineers-in-the-uk/

29. Women Engineering Association. https://www.wes.org.uk/content/nwed-blog

30. Women in Engineering. Geek Feminism Blog. https://geekfeminismdotorg. wordpress.com/tag/women-in-engineering/

\section{REFERENCES}

Adami, E. (2015). What's in a click? A social semiotic framework or the multimodal analysis of website interactivity. Visual Communication, 14 (2), 133-53. https://doi.org/10.1177/1470357214565583

Angouri, J. \& Marra, M. (Eds.), (2011). Constructing Identities at Work. Palgrave MacMillan. https://doi.org/10.1057/9780230360051

Baldry, A. \& Thibault, P. J. (2006). Multimodal transcription and text analysis: A multimedia toolkit and coursebook. Equinox.

Bateman, J.A. (2008). Multimodality and Genre. Palgrave MacMillan. https://doi. org/10.1057/9780230582323

Bateman, J.A, Wildfeuer, J \& Hippala, T. (2017). Multimodality - Foundations, research and analysis. A problem-oriented introduction. Mouton de Gruyter. https://doi.org/10.1515/9783110479898

Bezemer, J. \& C. Jewitt (2010). Multimodal Analysis: Key issues. In L. Litosseliti (Ed.), Research Methods in Linguistics (pp. 180-197). Continuum.

Bezemer, J \& Kress, G. (2008). Writing in multimodal texts: A social semiotic account of designs for learning. Written communication, 25 (2), 166-95. https://doi.org/10.1177/0741088307313177

Blood, R. (2000, September 7). Weblogs: A History and Perspective. Rebecca's Pocket. http://www.rebeccablood.net/essays/weblog_history.html. 
Buehl, J. (2016). Assembling Arguments: Multimodal Rhetoric and Scientific Discourse. University of South Carolina Press. ProQuest. https://doi. org/10.2307/j.ctv6wgfc3

Chandler, D. (1998). Personal Home Pages and the Construction of Identities on the Web. http://visual-memory.co.uk/daniel//Documents/short/webident. html

Daly, C. B. (1998). Introduction to Hypertext Writing Style. https://www.bu.edu/ cdaly/hyper.html

Girls in Tech. The Girls in Tech Blog (2020). https://girlsintech.org/blog/

Haciendo Balance (2019, July 3). Quiero Ser Ingeniera. https://blogs.upm.es/ quieroseringeniera/category/quiero-ser-ingeniera/

Jewitt, C., Bezemer, J., \& O'Halloran, K. (2016). Introducing multimodality. Routledge. https://doi.org/10.4324/9781315638027

Kress, G. \& van Leeuwen, Th. (1996/2006). Reading Images: The Grammar of Visual Design. Routledge. https://doi.org/10.4324/9780203619728

Kress, G. (2010). Multimodality: A Social Semiotic Approach to Contemporary Communication. Routledge.

Lauer, J. (2004). Invention in Rhetoric and Composition. Parlor Press.

LeFevre, K. B. (1986). Invention as a Social Act. Southern Illinois UP.

Lidón, I. (2019, March 4). ¿Por qué las mujeres no quieren ser ingenieras? El Mundo. https://www.elmundo.es/comunidad-valenciana/2019/03/04/5c7c60c12lefa065468b458d.html

Machin, D. (2007). Introduction to Multimodal Analysis. Arnold.

Manríquez, J. (2020, June 23) Día Internacional de la Mujer en la Ingeniería - INWED 2020. Mujer Ingeniera. https://www.mujeringeniera.com/ dia-internacional-mujer-ingenieria-inwed-2020.

Medalia, L. (2017, July 16). Productivity Tips. Laura Medalia. https://www.lauramedalia.com/blog/

Munn, M. (2014, July 15) Women Engineers Needed. Huffpost. https://www. huffingtonpost.co.uk/meg-munn/female-engineers_b_5584484.html

Osama, S. (2016, 26 September). 5 Myths About Women In Engineering - Busted. Top Universities. https://www.topuniversities.com/ blog/5-myths-about-women-engineering-busted

Pat (2014, Octobre 14). It's Ada Lovelace Day. Fairer Science. http://www.fairerscience.org/fs-blogs/index.html 
Pérez, J. I. (2020). Mujeres con ciencia. https://mujeresconciencia.com/ mujeres-con-ciencia/.

Pirini, J. (2017). Approaches to Multimodal Discourse Analysis. Oxford Bibliographies Online, Communication. https://doi.org/10.1093/ obo/9780199756841-0183

Popa, D. \& Gavriliu, D. (2015). Gender Representations and Digital Media. Procedia - Social and Behavioral Sciences, 180, 1199-1206. https://doi. org/10.1016/j.sbspro.2015.02.244

Quiero Ser Ingeniera (2019, March 1). El Blog de la BUA. https://blogs.ua.es/ bibliotecauniversitaria/2019/03/01/quiero-ser-ingeniera/

Rowsell, J. (2013). Working with Multimodality: Rethinking Literacy in a Digital Age. Routledge. https://doi.org/10.4324/9780203071953

Schnurr, S. (2013). Exploring Professional Communication. Language in Action. Routledge. https://doi.org/10.4324/9780203095324

Schnurr, S. \& Zayts, O. (2017). Language and Culture at Work. Routledge. https:// doi.org/10.4324/9781315541785

Stemettes (2020). https://stemettes.org/blog/

Stout, J.G., Dasgupta, N., Hunsinger, M., \& McManus, M.A. (2011). STEMing the tide: Using in-group experts to inoculate women's self-concept in science, technology, engineering, and mathematics (STEM). Journal of Personality and Social Psychology, 100(2), 255-270. https://doi.org/10.1037/a0021385

Swales, J. (2004). Research Genres. Exploration and Applications. Cambridge University Press. https://doi.org/10.1017/CBO9781139524827

Van Leeuwen, T. (1996). The representation of social actors. In C.R. CaldasCoulthard \& M. Coulthard (Eds.), Text and Practices: readings in critical discourse analysis (pp. 32-70). Routledge.

Van Leeuwen, T. (2005). Typographic meaning. Visual Communication, 4, 137143. https://doi.org/10.1177/1470357205053749

Van Leeuwen, T. (2011). The Language of Colour: An Introduction. Routledge. 